\title{
Anaerobic co-digestion of vegetable waste and swine wastewater in high-rate horizontal reactors with fixed bed
}

\author{
Raissa Cristina da Silva Mazareli ${ }^{\mathrm{a}}$, Rose Maria Duda ${ }^{\mathrm{a}}$, Valderi Duarte Leite ${ }^{\mathrm{b}}$, Roberto Alves de Oliveira ${ }^{\mathrm{c}, *}$ \\ ${ }^{a}$ Post-Graduate Program in Agricultural and Livestock Microbiology, Faculty of Agricultural and Veterinary Sciences, Univ Estadual Paulista, Campus of Jaboticabal, Department \\ of Rural Engineering, Laboratory of Environmental Sanitation, 14884-900 Jaboticabal, SP, Brazil \\ ${ }^{\mathrm{b}}$ Chemistry Department, Paraíba State University, Science and Technology Center, Floriano Peixoto - Bodocongo, 58100-000 Campina Grande, PB, Brazil

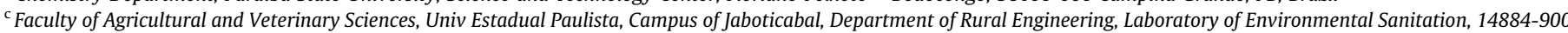 \\ Jaboticabal, SP, Brazil
}

\section{A R T I C L E I N F O}

\section{Article history:}

Received 9 July 2015

Revised 11 March 2016

Accepted 14 March 2016

Available online 4 April 2016

\section{Keywords:}

Anaerobic digestion

Biogas

Coliforms

Methane

Organic matter removal

Plug-flow reactor

\begin{abstract}
A B S T R A C T
Considering the high waste generation that comes from agriculture and livestock farming, as well as the demand for natural gas, it is necessary to develop sustainable technologies which can reduce environmental impact. There is no available literature on the use of high-rate horizontal anaerobic reactors with fixed bed (HARFB) and continuous feed for the co-digestion of vegetable wastes (VW) and swine wastewater (SW). The aim of this work was to evaluate the reactor performance in terms of methane production, organic matter consumption, and removal of total and thermotolerant coliforms under different proportions of SW and VW, and organic loading rates (OLR) of 4.0, 5.2 and 11.0 g COD (L d $)^{-1}$. The mixture of SW and VW in the proportions of 90:10, 80:20 and 70:30 (SW:VW) with those OLRs provided great buffering capacity, with partial alkalinity reaching $3552 \mathrm{mg} \mathrm{L}^{-1}$ thereby avoiding the inhibition of methane production by volatile fatty acids produced during the fermentation process. Higher proportions of $\mathrm{VW}$ and higher OLR improved volumetric methane production with a maximum value of $1.08 \mathrm{~L} \mathrm{CH}_{4}(\mathrm{~L} \mathrm{~d})^{-1}$, organic matter removal rates up to $98 \%$ and total and thermotolerant coliform removal rates of $99 \%$ were also observed.
\end{abstract}

(c) 2016 Elsevier Ltd. All rights reserved.

\section{Introduction}

Increasing worldwide demand for food and food by-products stems from the increase in human population and has resulted in the generation of large quantities of solid organic waste. Approximately $37 \%$ of the animal protein consumed worldwide comes from pig farming (McGlone, 2013). The intensification of livestock systems in feedlots result in the production of high volumes of wastewater from a small area (Abouelenien et al., 2014).

In the agricultural sector, approximately 1.5 billion ton/year of fruit and vegetable were produced worldwide and $45 \%$ of them were wasted. In Latin America, losses reach 55\% (FAO, 2011). In Brazil, approximately $60 \%$ of banana and up to $86 \%$ of tomato produced have been lost in the postharvest (Lichtemberg et al., 2008; Henz and Moretti, 2005). As a consequence of the build-up of solid organic waste in sanitary landfills, percolated liquids and greenhouse gases are produced because of the elevated concentrations of organic matter and humidity that come from this type of waste (Lin et al., 2011). These impacts can be reduced through the

\footnotetext{
* Corresponding author.

E-mail address: raoder@fcav.unesp.br (R.A.d. Oliveira).
}

exploration of renewable energy sources (Di Maria et al., 2015) and improvement or development of easy-to-implement locally adaptable solutions especially in developing countries (Duda et al., 2015).

Due to increased demand and rising prices for fossil fuels, vegetable biomass has already been converted into renewable energy as a sustainable alternative. In Europe nowadays, biomass contributes $4 \%$ of the total energy supply. According to the European Commission Renewable Energy Directive, the use of renewable energy should contribute 20\% by 2020 (Gissén et al., 2014).

Biogas production is one of several tools that may be used to alleviate the problems of global warming, energy security and waste management. Anaerobic digestion is an efficient alternative technology for the treatment of wastewater, agricultural waste, food processing waste, and fruit and vegetable debris as well as for sludge stabilization. Its advantages are the production of renewable fuel as biogas, the agricultural recycling of organic matter and the recovery of remaining nutrients in the effluents of the anaerobic reactors (Appels et al., 2011).

However, the solid waste from fruit and vegetables degrades quickly, which makes the acidification process easier, causing the accumulation of volatile fatty acids and consequently decreasing 
$\mathrm{pH}$, inhibiting the activity of methanogenic archaea (Bouallagui et al., 2009). The excess ammonia can also inhibit the microbial consortia responsible for methane production (Nielsen and Angelidaki, 2008). Consequently, the anaerobic digestion of vegetable biomass is used with low OLR, at most $3 \mathrm{~g}$ VS $(\mathrm{L} \mathrm{d})^{-1}$ without chemical supplementation (Jiang et al., 2012). The OLR can be increased by co-digestion with other biodegradable substrate (Bolzonella et al., 2006). The increase of OLR of 2.4-6.0 g VS $(\mathrm{Ld})^{-1}$ in a food and fruit-vegetable wastes co-digestion with dewatered sewage sludge in anaerobic digester (CSTR) led to an increase of over $100 \%$ in methane production, of $0.97-2.40 \mathrm{~L}$ $(\mathrm{Ld})^{-1}$, maintaining the percentage of methane between 56 and $57 \%$ (Liu et al., 2012). With a higher OLR, of $7.5 \mathrm{~g} \mathrm{VS} \mathrm{(L} \mathrm{d)}{ }^{-1}$, the co-digestion of grass, cow manure and fruit-vegetable wastes in CSTR reached maximum methane production of $0.94 \mathrm{~L}(\mathrm{~L} \mathrm{~d})^{-1}$ (Ganesh et al., 2013). Thus, besides of OLR the type of waste used in the anaerobic co-digestion can affect methane production.

In order to enhance biogas production, the improvement of reactor design has a strong effect on anaerobic digestion performance (Namsree et al., 2012). Developed for the anaerobic treatment of liquid effluents, high-rate anaerobic reactors are characterized by their ability to retain large quantities of microbial biomass and allow for the use of low hydraulic detention time (HDT) and high OLR, which differs from conventional digesters. Particularly, horizontal anaerobic reactors with fixed bed (HARFB) a new generation of high-rate biological reactors, where it is possible to maintain high concentrations of biomass immobilized on the support, permit continuous horizontal outflows that approach plug-flow and HDT relatively short for high OLR (Zaiat et al., 1994; Ghaniyari-Benis et al., 2009). Besides, they provide advantages such as low area requirements and structural complexity facilitating their implementation in small and large scale (Oliveira and Bruno, 2013).

The HARFB have shown great efficiency for biogas production and organic matter removal from different agricultural and livestock effluents. The use of in-series HARFB for the treatment of SW and coffee fruit processing wastewater increased suspended solids, chemical oxygen demand (COD), metals, and coliform bacteria removals and methane production, while reducing HDT and improving system stability (Santos and Oliveira, 2011; Oliveira and Bruno, 2013; Duda et al., 2015).

However, there is no available information in the literature about the use of HARFB for the co-digestion of VW, because that has generally been conducted in batch and continuous completemix digesters with semi-solid and solid affluents. Therefore, the aim of this work was to evaluate methane production, removal of organic matter and coliforms in the anaerobic co-digestion process in HARFB using liquid affluents with high suspended solids concentrations, of $2-10 \mathrm{~g} \mathrm{~L}^{-1}$. This is the first time that such reactors have been evaluated for the treatment of SW and VW in different co-digestion proportions.

\section{Materials and methods}

\subsection{Substrate}

The SW was collected three times a week from feedlot system during growing-finishing phase. This wastewater was sieved in $3 \mathrm{~mm}$ mesh.

The VW (banana and tomato) was collected in grocery stores, milled in industrial blender and then sieved in $2 \mathrm{~mm}$ mesh. The banana and tomato extract was stored in a freezer due to large volumes needed for the tests. VW consisted of $70 \%$ tomato and $30 \%$ banana extracts by wet volume.
The SW and a mixture of SW and VW constituted the substrates used as affluent for the reactors system and their characteristics are shown in Table 1.

\subsection{Reactor configuration, start-up and operation}

The experimental system consisted of an affluent storage reservoir and three in-series HARFB (R1, R2 and R3) at pilot scale (Fig. 1). The HARFB were built according to Zaiat et al. (1994). Characteristics of the experimental setup are detailed in Table 2. The HARFBs were built with $6 \mathrm{~m}$ PVC tubes with internal diameters of $0.108,0.153$ and $0.191 \mathrm{~m}$ to obtain relations $\mathrm{L} / \mathrm{D}>25$ and consequently plug-flow reactors (Sauer et al., 2015).

The reactors system was arranged so that the speeds were decreasing from the first to the third reactor (Table 3 ). In order to enhance the conversion of soluble organic compounds in the first reactor, increase the time to hydrolysis, and decrease the drag of organic suspended solids in the second and third reactors. Thereby improve the production of methane and the quality of the final effluent.

To build the fixed bed for biomass immobilization, the reactors were totally filled with bamboo rings with specific surface area of $92.5 \mathrm{~m}^{2} \mathrm{~m}^{-3}$, with average length and diameter of $0.046 \mathrm{~m}$ and $0.025 \mathrm{~m}$, respectively. The bamboo rings with $75 \%$ empty space provided the support medium for fixed bed reactors R1-3. There was no clogging problem with the proportions SW:VW used.

At the top of each reactor were made six orifices for biogas exits. These were interconnected and coupled to a gasometer to store the biogas produced daily (Fig. 1). The reactors have registers along their length: seven on the sides to collect effluent samples, and six on the lower part to collect sludge.

The reactors were inoculated with anaerobic sludge from HARFB used by Duda et al. (2015) to treat SW. The inoculum sludge had concentrations of total solids (TS) $16 \mathrm{~g} \mathrm{~L}^{-1}$ and volatile solids (VS) $12 \mathrm{~g} \mathrm{~L}^{-1}$. To start-up the inoculated amount was $30 \%$ of total volume for each reactor.

Four experimental tests (1-4) with durations of 65, 53, 46 and 37 days were run, totaling 201 days of reactors operation. The reactors system was operated at room temperature and the average air temperatures were $22^{\circ} \mathrm{C}, 19^{\circ} \mathrm{C}, 20^{\circ} \mathrm{C}$ and $24^{\circ} \mathrm{C}$ in the tests $1-4$, respectively. The end of each test was reached when the biogas production was stable. The operational conditions of reactors system are show in Table 3.

The HDT and OLR were defined from experimental results obtained by Duda et al. (2015) in treatment system with HARFB. Using SW with COD of $5886 \mathrm{mg} \mathrm{L}^{-1}$ applied OLR 12-33 g COD $(\mathrm{Ld})^{-1}$ and HDT $1 \mathrm{~d}$ obtained $\mathrm{COD}_{\text {total }}$ removal efficiencies below $80 \%$ and methane volumetric production around $1.0 \mathrm{~L}(\mathrm{Ld})^{-1}$. In view of the risk of acidification with VW mixture, for start-up in test 1 OLR around $5 \mathrm{~g} \mathrm{COD}$ total $(\mathrm{Ld})^{-1}$ was adopted which resulted in $2 \mathrm{~d}$ HDT in R1. OLR of tests 2-4 were the result of the $\mathrm{COD}_{\text {total }}$ of mixture of increasing proportions of VW divided by HDT $2 \mathrm{~d}$ in R1.

Therefore, in the test 1 , the affluent of reactors system was SW. In the test 2, the affluent was the mixture of SW and 10\% of VW. In the tests 3 and 4, the mixture had volume of VW increased to $20 \%$ and $30 \%$, respectively (Table 1 ).

The HDT in reactor system was $13 \mathrm{~d}$ in the four tests. In the first reactor, it was $2.0 \mathrm{~d}$, second $4.5 \mathrm{~d}$ and third $6.5 \mathrm{~d}$. Consequently, the OLR applied in the first (R1) reactor was obtained by the division between affluent $\mathrm{COD}_{\text {total }}$ of each test (Table 1) and HDT of $2.0 \mathrm{~d}$. The characteristics of SW varied during the experiment and its $\mathrm{COD}_{\text {total }}$ decreased in the tests 2 and 3 because of the variations in age of the pigs and the amount of water used in feedlot system. Thus, the OLR in the tests 2 and 3 were lower. The OLR in second (R2) and third (R3) reactors varied depending on the values of 
Table 1

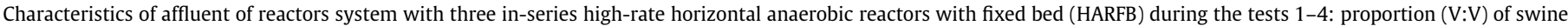
wastewater (SW) and vegetable waste (VW); mean values and variation coefficients (v.c.) of determinations of organic and inorganic constituents.

\begin{tabular}{|c|c|c|c|c|c|c|c|c|}
\hline \multirow[t]{2}{*}{ Affluent } & \multicolumn{8}{|l|}{ Test } \\
\hline & 1 & v.c. & 2 & v.c. & 3 & v.c. & 4 & v.c. \\
\hline Proportion SW:VW & $100: 0$ & - & $90: 10$ & - & $80: 20$ & - & $70: 30$ & - \\
\hline $\mathrm{COD}_{\text {total }}$ & 11,187 & 49 & 7947 & 52 & 10,461 & 20 & 22,106 & 25 \\
\hline $\mathrm{COD}_{\text {diss }}$ & 2281 & 64 & 4073 & 37 & 4220 & 26 & 5627 & 31 \\
\hline TSS & 6370 & 76 & 2690 & 113 & 4410 & 85 & 9560 & 109 \\
\hline VSS & 5320 & 74 & 2280 & 117 & 3835 & 28 & 8610 & 99 \\
\hline $\mathrm{N}_{\text {total }}$ & 617 & 41 & 573 & 37 & 464 & 78 & 806 & 53 \\
\hline $\mathrm{N}_{\mathrm{am}}$ & 348 & 47 & 352 & 43 & 481 & 24 & 360 & 50 \\
\hline $\mathrm{P}_{\text {total }}$ & 70 & 57 & 29 & 59 & 72 & 16 & 107 & 30 \\
\hline $\mathrm{pH}$ & 6.8 & 3 & 5.7 & 13 & 5.7 & 8 & 5.2 & 3 \\
\hline VFA & 1067 & 55 & 1794 & 37 & 3120 & 20 & 4441 & 24 \\
\hline
\end{tabular}

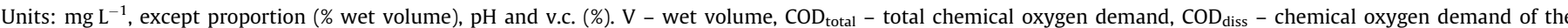

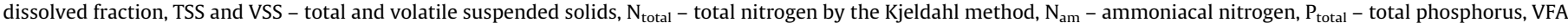
- volatile fatty acids and v.c. - variation coefficient $=($ standard deviation $/$ mean $) * 100$.

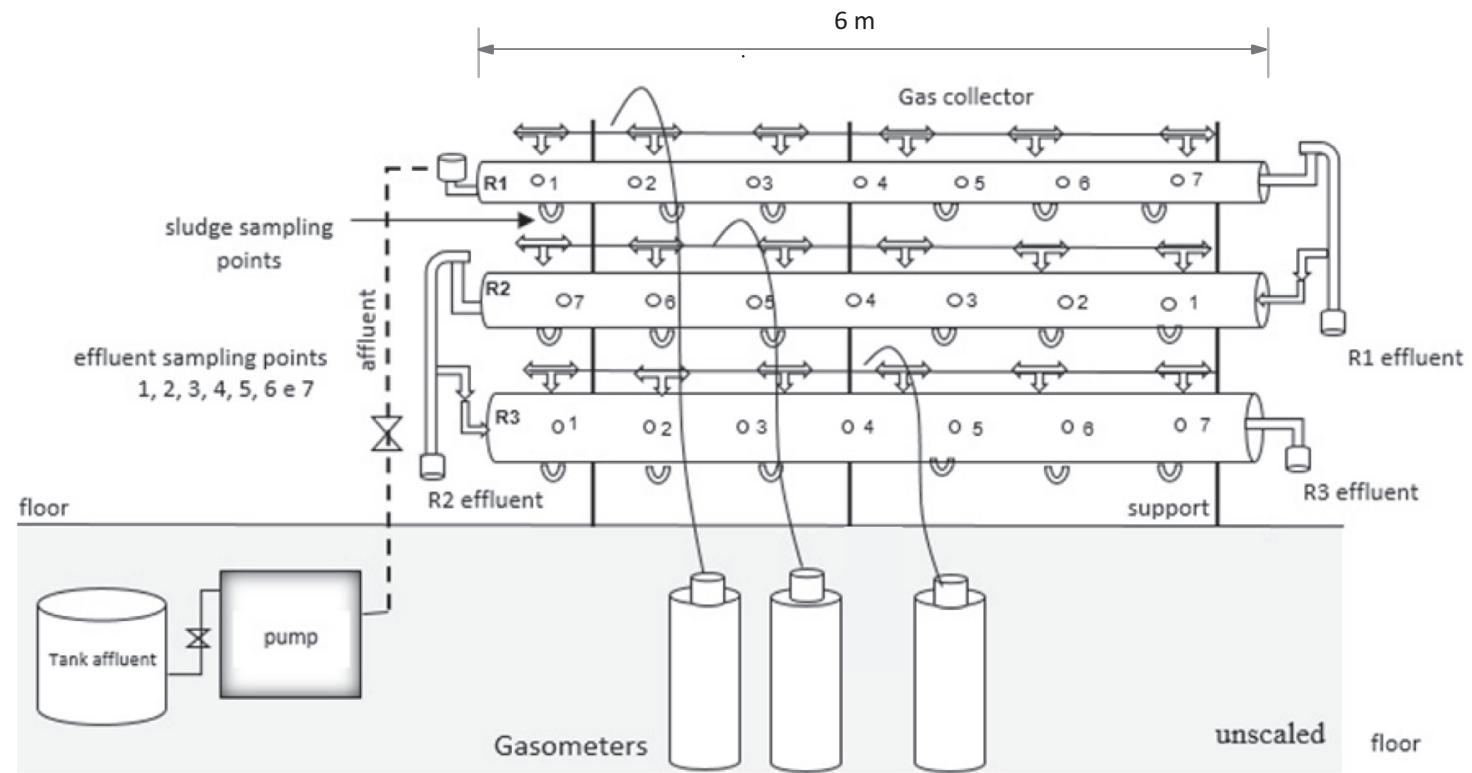

Fig. 1. Schematic representation of the treatment system with three in-series high-rate horizontal anaerobic reactors with fixed bed (HARFB) (R1, R2 and R3).

Table 2

Values of diameter, length, total and useful volumes of three in-series high-rate horizontal anaerobic reactors with fixed bed (HARFB).

\begin{tabular}{lllrr}
\hline Reactor & Diameter (internal) & Length & \multicolumn{2}{c}{ Volume } \\
\cline { 3 - 5 } & & & Total & Useful \\
\hline R1 & 0.105 & 6.0 & 52.0 & 39.0 \\
R2 & 0.156 & 6.0 & 115.3 & 86.5 \\
R3 & 0.191 & 6.0 & 171.9 & 128.9
\end{tabular}

Units: diameter and length (m) and total and useful volume (L); R1, R2 and R3 first, second and third in-series HARFB.

the effluents $\mathrm{COD}_{\text {total }}$ from the first and second reactors, respectively (Table 3 ).

\subsection{Parameters, analytical methods and sampling}

To assess reactors system performance, affluent and effluents were sampled twice weekly. The composite samples of affluent (inlet of R1) and effluents (output of R1, R2 and R3) were composed of single samples of $200 \mathrm{ml}$, which were collected every $30 \mathrm{~min}$ during $6 \mathrm{~h}$. The sludge was collected biweekly in sampling points from three HARFB (Fig. 1).

The physical examinations and organic and inorganic constituents determinations included total and dissolved chemical oxygen demand $\left(\mathrm{COD}_{\text {total }}\right.$ and $\left.\mathrm{COD}_{\text {diss }}\right)$; total and volatile suspended solids (TSS and VSS); volatile solids (VS); $\mathrm{pH}$; total, partial and intermediate alkalinity (TA, PA, and IA); total volatile fatty acids (VFA), and total and thermotolerant coliforms according to the methodologies described in APHA (2005), Jenkins et al. (1983), Ripley et al. (1986) and DiLallo and Albertson (1961). Biogas production volume was assessed daily in the gasometers, and biogas composition was analyzed weekly by gas chromatography, as described in APHA (2005). The results of the methane production were reported at standard temperature and pressure (STP, $101.325 \mathrm{kPa}, 273.15 \mathrm{~K})$.

\section{Results and discussion}

\subsection{Buffering capacity}

The affluent had pH values that decreased with increasing VW concentration in the mixture (Table 1 ). The $\mathrm{pH}$ of SW was neutral 
Table 3

Operational conditions of reactors system with three in-series high-rate horizontal anaerobic reactors with fixed bed (HARFB) during the tests $1-4$.

\begin{tabular}{|c|c|c|c|c|c|c|c|c|c|c|c|c|}
\hline \multirow[t]{3}{*}{ Parameter } & \multicolumn{12}{|c|}{$\begin{array}{l}\text { Test } \\
\text { (\%SW:\%VW) }\end{array}$} \\
\hline & \multicolumn{3}{|c|}{$\begin{array}{l}1 \\
(100: 0)\end{array}$} & \multicolumn{3}{|c|}{$\begin{array}{l}2 \\
(90: 10)\end{array}$} & \multicolumn{3}{|c|}{$\begin{array}{l}3 \\
(80: 20)\end{array}$} & \multicolumn{3}{|c|}{$\begin{array}{l}4 \\
(70: 30)\end{array}$} \\
\hline & $\mathrm{R} 1$ & $\mathrm{R} 2$ & R3 & $\mathrm{R} 1$ & $\mathrm{R} 2$ & R3 & $\mathrm{R} 1$ & $\mathrm{R} 2$ & R3 & $\mathrm{R} 1$ & $\mathrm{R} 2$ & R3 \\
\hline $\mathrm{v}$ & 2.3 & 1.0 & 0.7 & 2.3 & 1.0 & 0.7 & 2.3 & 1.0 & 0.7 & 2.3 & 1.0 & 0.7 \\
\hline HDT & 2.0 & 4.5 & 6.5 & 2.0 & 4.5 & 6.5 & 2.0 & 4.5 & 6.5 & 2.0 & 4.5 & 6.5 \\
\hline OLR & 5.5 & 0.9 & 0.1 & 4.0 & 1.5 & 0.1 & 5.2 & 3.1 & 0.2 & 11.0 & 4.1 & 0.2 \\
\hline
\end{tabular}

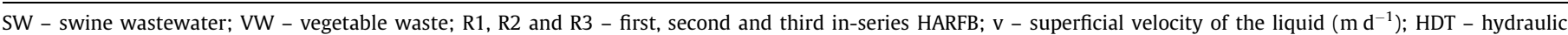
detention time $(\mathrm{d})$; OLR - organic loading rate $\left(\mathrm{g} \mathrm{COD}_{\text {total }}(\mathrm{Ld})^{-1}\right)$.

(Urbinati et al., 2013). In contrast, the pH of VW was from 4 to 5 , which was not favorable for the growth of methanogenic archaea (Leite et al., 2014). The pH of the first VW and SW mixture was approximately 6.4, a fact also reported by Xie et al. (2011) in the waste co-digestion process of pig farming and grass silage. According to Chen et al. (2013), abundant carbohydrates in the substrates used for anaerobic digestion, such as food waste, are attacked by microorganisms that degrade the polysaccharides to monomers; thereafter, pyruvate is oxidized to acetyl-CoA to form acids, such as acetate. Kim et al. (2003) reported that hydrolysis and acidogenesis occurs efficiently at $\mathrm{pH} 5.5$ and 6.5 , respectively. This fact can be shown by the fall of $\mathrm{pH}$ from 6.4 to 5.2 and the high total fatty

Table 4

Average values and variation coefficient (v.c.) of $\mathrm{pH}$, volatile fatty acids (VFA), partial alkalinity (PA), the ratio of intermediate and partial alkalinity (IA/PA) and ammoniacal nitrogen $\left(\mathrm{N}_{\mathrm{am}}\right)$ in affluent and effluents of three in-series high-rate horizontal anaerobic reactors with fixed bed (HARFB) during the tests 1-4.

\begin{tabular}{|c|c|c|c|c|c|c|}
\hline \multirow[t]{2}{*}{ Test (\%SW:\%VW) } & \multirow[t]{2}{*}{ Measurement site } & \multicolumn{5}{|c|}{ Parameter } \\
\hline & & $\mathrm{pH}$ & VFA & PA & IA/PA & $\mathrm{N}_{\mathrm{am}}$ \\
\hline \multirow{8}{*}{$(100: 0)$} & Affluent & 6.8 & 1067 & 643 & - & 348 \\
\hline & v.c. & 3 & 55 & 42 & - & 47 \\
\hline & $\mathrm{R} 1$ & 7.4 & 486 & 1211 & 0.60 & 370 \\
\hline & v.c. & 2 & 51 & 42 & 97 & 42 \\
\hline & $\mathrm{R} 2$ & 7.2 & 303 & 1343 & 0.40 & 379 \\
\hline & v.c. & 4 & 50 & 50 & 43 & 48 \\
\hline & R3 & 7.4 & 237 & 1205 & 0.36 & 377 \\
\hline & v.c. & 2 & 55 & 49 & 32 & 52 \\
\hline \multirow{8}{*}{${ }^{2}$ (90:10) } & Affluent & 5.7 & 1794 & 208 & - & 352 \\
\hline & v.c. & 13 & 37 & 122 & - & 43 \\
\hline & $\mathrm{R} 1$ & 7.2 & 652 & 1177 & 0.62 & 408 \\
\hline & v.c. & 2 & 38 & 39 & 27 & 31 \\
\hline & $\mathrm{R} 2$ & 7.3 & 493 & 1414 & 0.39 & 426 \\
\hline & v.c. & 1 & 52 & 32 & 33 & 27 \\
\hline & R3 & 7.4 & 480 & 1373 & 0.35 & 444 \\
\hline & v.c. & 1 & 44 & 20 & 28 & 28 \\
\hline \multirow{8}{*}{$(80: 20)$} & Affluent & 5.7 & 3120 & 182 & - & 481 \\
\hline & v.c. & 8 & 20 & 173 & - & 24 \\
\hline & R1 & 7.3 & 872 & 1959 & 0.67 & 692 \\
\hline & v.c. & 2 & 41 & 23 & 42 & 17 \\
\hline & $\mathrm{R} 2$ & 7.5 & 457 & 2526 & 0.32 & 701 \\
\hline & v.c & 1 & 44 & 15 & 20 & 14 \\
\hline & R3 & 7.3 & 405 & 2578 & 0.28 & 672 \\
\hline & v.c & 1 & 46 & 11 & 21 & 8 \\
\hline \multirow{8}{*}{$(70: 30)$} & Affluent & 5.2 & 4441 & 0 & - & 359 \\
\hline & v.c. & 3 & 24 & - & - & 50 \\
\hline & $\mathrm{R} 1$ & 7.4 & 1353 & 2382 & 0.73 & 701 \\
\hline & v.c. & 3 & 64 & 34 & 50 & 31 \\
\hline & $\mathrm{R} 2$ & 7.8 & 499 & 3417 & 0.24 & 826 \\
\hline & v.c. & 2 & 37 & 16 & 15 & 11 \\
\hline & R3 & 7.9 & 378 & 3552 & 0.21 & 798 \\
\hline & v.c. & 2 & 39 & 15 & 24 & 7 \\
\hline
\end{tabular}

Units: VFA - mg L ${ }^{-1} \mathrm{CH}_{3} \mathrm{COOH}, \mathrm{PA}-\mathrm{mg} \mathrm{L}^{-1} \mathrm{CaCO}_{3}, \mathrm{~N}_{\mathrm{am}}-\mathrm{mg} \mathrm{L}^{-1} \mathrm{~N}$, v.c. - \%. SW swine wastewater; VW - vegetable waste; R1, R2 and R3 - first, second and third in-series HARFB. acids (VFA) concentrations in the affluents used for the tests 2, 3 and 4, when the VW concentration used was increased (Table 4).

The $\mathrm{pH}$ values were higher in reactors effluents than in the affluent, with average values between 7.2 and 7.9, indicating buffering capacity of reactors, which favored methanogenic archaea metabolism and stability of the system. Lin et al. (2011) verified that the fruit and vegetable waste had lower acidification potential when co-digested with food waste, and these suitable conditions improved the buffering capacity of the anaerobic codigestion process.

The present data indicate that, at VW fractions up to $30 \%$, with higher OLR applied, it was possible to keep the buffering system in suitable conditions on the three HARFB. The PA values in the effluent of reactors system (R3) increased to 1205, 1373, 2578 and $3552 \mathrm{mg} \mathrm{L}^{-1}$, in the tests $1,2,3$ and 4 , respectively (Table 4). Bouallagui et al. (2009) also observed higher effluent PA values from 1300 to $7000 \mathrm{mg} \mathrm{L}^{-1}$ in the co-digestion of fruit and vegetable waste with slaughterhouse wastewater. The higher PA values in the effluent in comparison to the affluent indicate an increase in bicarbonate alkalinity, further showing the buffering capacity of the system.

The satisfactory performance of the buffering system of the reactors was also observed through the relation IA/PA, with values between 0.21 and 0.36 in effluent of reactors system (R3), indicating the consumption of volatile fatty acids (Table 4 ). The values were at the recommended level in all the reactors, except for R1, in which the values increased of $0.60-0.73$ in the tests $1-4$. The values were lower in the R2 and R3 effluents of the test 4, evidencing the effectiveness of using the co-digestion and in-series reactors to stabilize the treatment system. Therefore, even with the increase of OLR from 5.5 to $11.0 \mathrm{~g} \mathrm{COD}_{\text {total }}(\mathrm{Ld})^{-1}$, the reactors remained stable, as evidenced by the decreasing values of IA/PA.

The VFA concentration in the R1 effluent increased with the VW quantity in the affluent, and consequently with the OLR in the tests 1-4 (Table 4), due to the higher availability of organic matter in the affluent. This increase of VFA with OLR were also reported by Nagao et al. (2012) that increased the OLR from 3.7 to $12.9 \mathrm{~g}$ VS $(\mathrm{Ld})^{-1}$ and the VFA concentration reached $19,210 \mathrm{mg} \mathrm{L}^{-1}$ in semi-continuous digesters fed with food waste. These authors observed biogas production inhibition with VFA concentrations of $8149 \mathrm{mg} \mathrm{L}^{-1}$. This fact was related to the higher activity of hydrolytic and acidogenic bacteria than to methanogenic archaea in $\mathrm{R} 1$ sludge, which can be inhibited in acidic conditions (Wang et al., 2014). Except in R1, the effluent VFA values remained lower than $400 \mathrm{mg} \mathrm{L}^{-1}$ in all the reactors (R2 and R3), and adequate for the stable operation of the anaerobic treatment system with high methane production (Fig. 3).

The $\mathrm{N}_{\mathrm{am}}$ concentrations in the affluent and effluent increased among the tests; with the VW proportion and OLR having increased, higher concentrations of protein compounds consequently became available for ammonification (Table 4). Appropriate concentrations of ammonia in the anaerobic reactor increased 
the buffering capacity, due to the formation of $\mathrm{NH}_{4} \mathrm{HCO}_{3}$ (Murto et al., 2004). Wang et al. (2014) reported a linear increase of $\mathrm{N}_{\mathrm{am}}$ concentration with the fermentation at $\mathrm{pH} 5$ and $\mathrm{pH} 6$, and observed inhibition of hydrolytic and acidogenic microbiota by ammonia. Only in more acidic conditions $(\mathrm{pH} 4)$ the remaining concentrations were low and stable. Angelidaki and Ahring (1993) observed ammonia toxicity, which resulted in a reduction in methane production, and consequently a VFA increase. The methane production was reduced by $25 \%$ when the $\mathrm{N}_{\text {am }}$ concentrations increased from 4000 to $6000 \mathrm{mg} \mathrm{L}^{-1}$. The test 4 presented the highest increases of $\mathrm{N}_{\mathrm{am}}$, of $360 \mathrm{mg} \mathrm{L}^{-1}$ in the affluent to $798 \mathrm{mg} \mathrm{L}^{-1}$ in the R3 effluent. The strongest ammonification cooccurred with the highest VFA production, which were both due to the intensification of the activity of acidogenic and hydrolytic bacteria and to the OLR and VW proportion increase. However, the $\mathrm{N}_{\mathrm{am}}$ values were too low to cause toxicity in the hydrogenotrophic and acetoclastic methanogenic microbiota, whereas methane production was observed in all reactors (Fig. 3) and PA remained high (Table 4 ).

The present study demonstrated that treatment systems based on in-series HARFB can produce enough alkalinity and maintain a $\mathrm{pH}$ appropriate for the conversion of VFA by acetogenic and methanogenic microorganisms, even with increasing VFA in the affluent up to $4441 \mathrm{mg} \mathrm{L}^{-1}$ (Table 4) and OLR of $11.0 \mathrm{~g} \mathrm{COD}_{\text {total }}(\mathrm{Ld})^{-1}$.

\subsection{Effect of increasing VW fraction and OLR on the anaerobic co- digestion}

\subsubsection{Organic matter removal}

It has been found that average values of $\operatorname{COD}_{\text {total }}$, TSS and VSS were only significantly higher in the test 4 , when a higher proportion of VW was used ( $30 \%$ in wet volume) (Table 5). However, variation in the quality of SW must also be taken into consideration because the test 4 coincided with the end of swine termination phase, when the VSS concentration increases in manure.

The parameters that best correlated to the affluent alterations were $\mathrm{COD}_{\text {diss, }}$ VFA and $\mathrm{pH}$. The average values of $\mathrm{COD}_{\text {diss }}$ and VFA increased, and the $\mathrm{pH}$ values decreased gradually from the test 1 to 4 because of the increase of VW proportion in the affluent
(Table 5). Wang et al. (2014) observed a similar behavior of COD $_{\text {diss }}$ and $\mathrm{pH}$, which confirmed that the acid conditions of VW contributed to the hydrolysis and acidification of organic macromolecules in waste.

There was gradual increase in the values of $\mathrm{COD}_{\text {total }}, \mathrm{COD}_{\text {diss }}$, TSS and VSS in the effluents from reactors system over the course of the tests $1-4$, responding to the increase in affluent VW proportion and the OLR (Table 5). The $\mathrm{COD}_{\text {total }}$ of SW applied into R1 was higher than described by Yang et al. (2015) of $5692 \mathrm{mg} \mathrm{L}^{-1}$ and Duda et al. (2015) of $5868 \mathrm{mg} \mathrm{L}^{-1}$. Larger concentrations of $\mathrm{COD}_{\text {total }}, \mathrm{COD}_{\text {diss }}$, TSS and VSS occurred in the R1 effluent due to application of smaller HDT and a greater liquid velocity (v) and OLR to this reactor. The carbohydrates present in the highest concentrations in the VW were hydrolyzed and fermented by acidogenic microorganisms, leading to VFA formation. In the anaerobic digestion of VW, Zuo et al. (2013) observed the predominance of fermentative bacteria in the sludge, which made the hydrolysis easier, increasing the $\mathrm{COD}_{\text {diss }}$ concentration, which resulted in high concentrations of VFA. Even with the high VFA concentrations in affluent, no inhibition of acetogenic bacteria and methanogenic archaea was observed because the $\mathrm{COD}_{\text {diss }}$ removal (Table 5 and Fig. 2) and methane production (Fig. 3) remained stable in R1 and R2. It has been reported studies on acclimation of anaerobic sludge to several inhibitors, including long-chain fatty acids (LCFA) (Fernández et al., 2005), which might occur in anaerobic reactors. With the strategy of start-up and operation of HARFBs using SW in the test 1 and the gradual increase of VW in the tests 2-4, sludge acclimation and accumulation (Fig. 4) occurred (especially in R1 and R2), and it was possible to maintain high COD and SS removal (Table 4) with increasing methane production (Fig. 3) in the treatment system.

Despite the increase in VW proportion in the affluent and OLR during the tests 3 and 4, there was no inhibition of the anaerobic microbiota's ability to remove COD and VSS and convert them into VFA and methane in treatment system because the buffering system successfully prevented the accumulation of acids and a decrease in $\mathrm{pH}$ (Table 3$)$. When the tests 2-4 (SW + VW) were compared to the test $1(\mathrm{SW})$, it was observed that a small increase of $\mathrm{COD}_{\text {total }}$ and $\mathrm{COD}_{\text {diss }}$ removals occurred (Fig. 2) with VW addition

Table 5

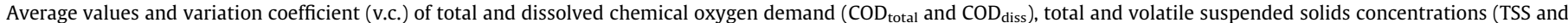
VSS) in affluent and effluents, and removal efficiencies (R1 + R2 + R3) of three in-series high-rate horizontal anaerobic reactors with fixed bed (HARFB) during the tests 1-4.

\begin{tabular}{|c|c|c|c|c|c|c|c|c|c|}
\hline \multirow[t]{2}{*}{ Parameter } & \multirow[t]{2}{*}{ Measurement site } & \multicolumn{8}{|c|}{ Test (\%SW:\%VW) } \\
\hline & & $\begin{array}{l}1 \\
(100: 0)\end{array}$ & v.c. & $\begin{array}{l}2 \\
(90: 10)\end{array}$ & v.c. & $\begin{array}{l}3 \\
(80: 20)\end{array}$ & v.c. & $\begin{array}{l}4 \\
(70: 30)\end{array}$ & v.c \\
\hline \multirow[t]{5}{*}{$\mathrm{COD}_{\text {total }}$} & Affluent & 11,187 & 49 & 7947 & 52 & 10,461 & 20 & 22,106 & 25 \\
\hline & $\mathrm{R} 1$ & 4179 & 87 & 6672 & 69 & 14,060 & 37 & 18,334 & 19 \\
\hline & $\mathrm{R} 2$ & 537 & 47 & 575 & 42 & 1087 & 37 & 1490 & 39 \\
\hline & R3 & 375 & 37 & 366 & 42 & 612 & 27 & 846 & 22 \\
\hline & $\mathrm{R} 1+\mathrm{R} 2$ + R3 & 93 & 11 & 92 & 2 & 94 & 1 & 94 & 1 \\
\hline \multirow[t]{5}{*}{$\operatorname{COD}_{\text {diss }}$} & Affluent & 2281 & 64 & 4073 & 37 & 4220 & 26 & 5627 & 31 \\
\hline & $\mathrm{R} 1$ & 1080 & 64 & 1453 & 47 & 3442 & 108 & 3155 & 77 \\
\hline & $\mathrm{R} 2$ & 390 & 46 & 508 & 47 & 828 & 28 & 1229 & 34 \\
\hline & R3 & 284 & 29 & 269 & 37 & 514 & 28 & 707 & 30 \\
\hline & $\mathrm{R} 1+\mathrm{R} 2$ + R3 & 85 & 13 & 92 & 2 & 87 & 2 & 86 & 2 \\
\hline \multirow[t]{5}{*}{ TSS } & Affluent & 6370 & 76 & 2690 & 113 & 4410 & 85 & 9560 & 109 \\
\hline & $\mathrm{R} 1$ & 1579 & 111 & 4243 & 49 & 8580 & 37 & 13,985 & 43 \\
\hline & $\mathrm{R} 2$ & 94 & 107 & 95 & 63 & 232 & 40 & 289 & 50 \\
\hline & R3 & 75 & 107 & 87 & 57 & 85 & 40 & 131 & 59 \\
\hline & $\mathrm{R} 1+\mathrm{R} 2$ + R3 & 97 & 5 & 93 & 5 & 96 & 2 & 97 & 0,4 \\
\hline \multirow[t]{5}{*}{ VSS } & Affluent & 5320 & 74 & 2280 & 117 & 3835 & 28 & 8610 & 99 \\
\hline & $\mathrm{R} 1$ & 1322 & 111 & 3088 & 55 & 6910 & 37 & 11,558 & 44 \\
\hline & $\mathrm{R} 2$ & 62 & 81 & 64 & 56 & 172 & 51 & 218 & 58 \\
\hline & R3 & 41 & 90 & 49 & 42 & 50 & 40 & 78 & 58 \\
\hline & $\mathrm{R} 1+\mathrm{R} 2+\mathrm{R} 3$ & 98 & 5 & 95 & 3 & 97 & 1 & 98 & 1 \\
\hline
\end{tabular}

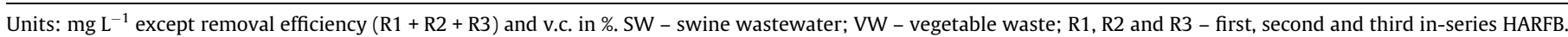



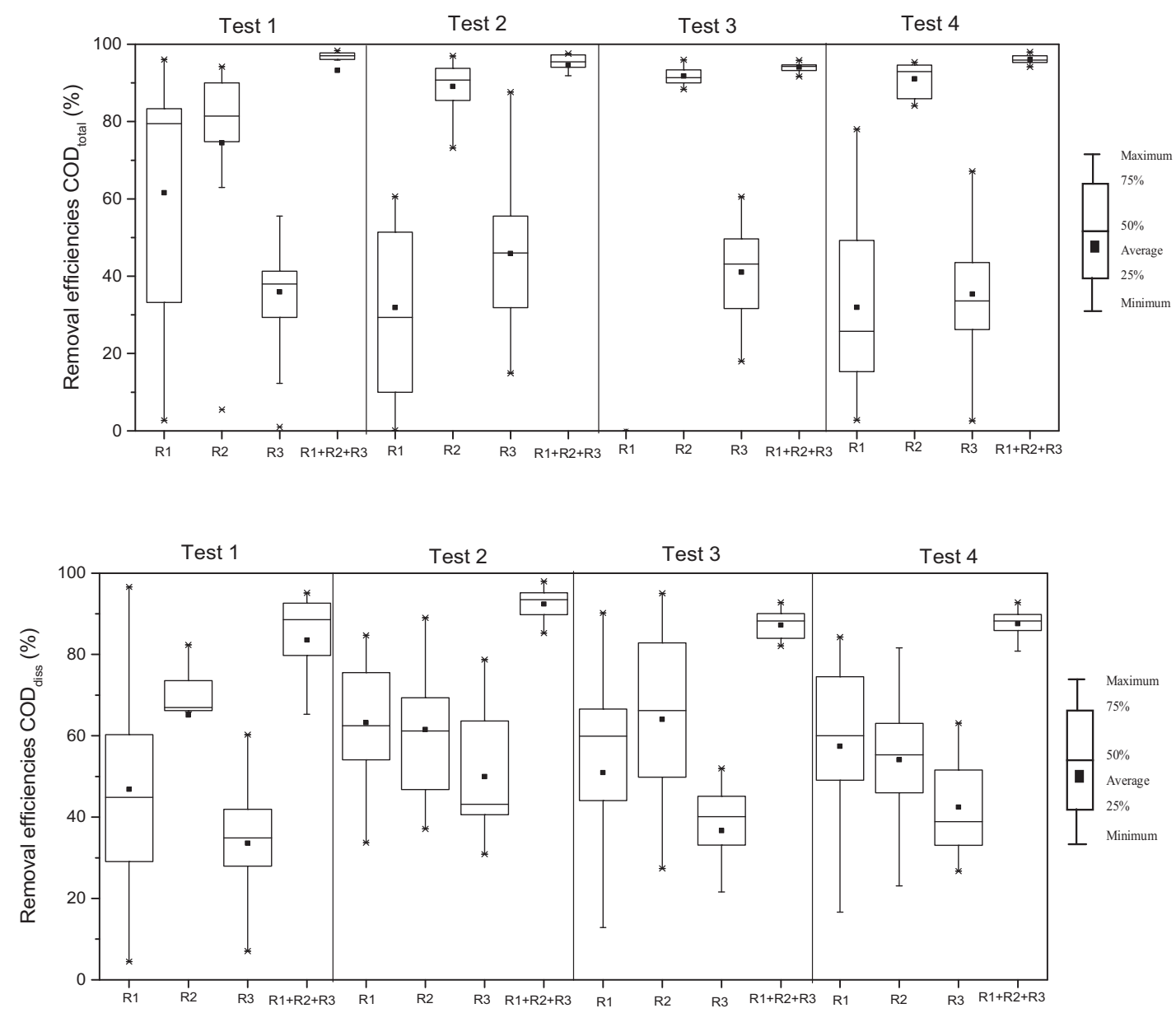

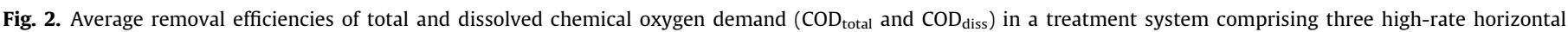
reactors with fixed bed (HARFB) installed in series (R1, R2 and R3), during the tests 1 (100\% SW), 2 (90\% SW:10\% VW), 3 (80\% SW:20\% VW), and 4 (70\% SW:30\% VW).

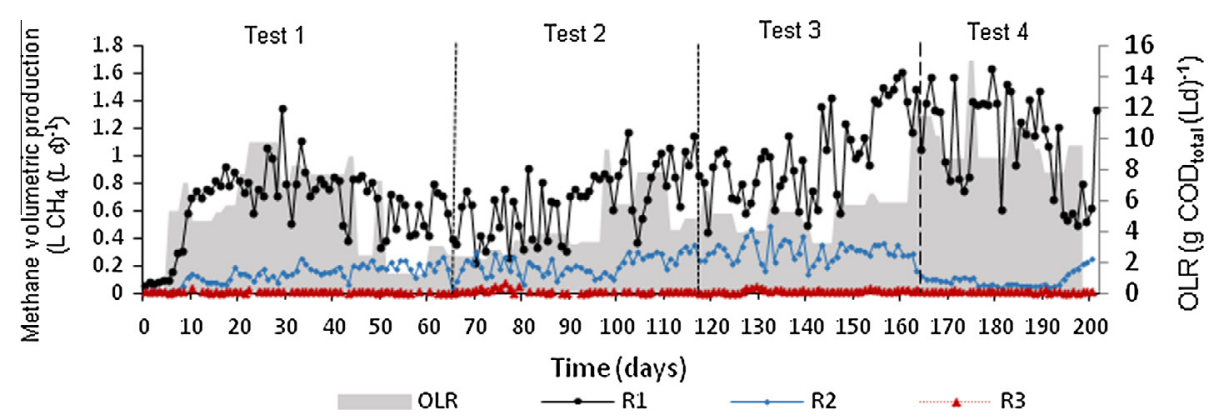

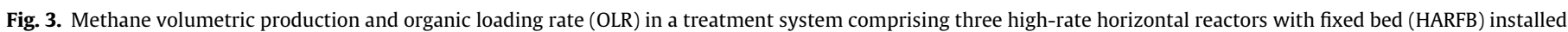
in series (R1, R2 and R3), during the tests 1 (100\% SW), 2 (90\% SW:10\% VW), 3 (80\% SW:20\% VW), and 4 (70\% SW:30\% VW).

to the affluent. This is consistent because the VW addition increases the biodegradability and consequently improves hydrolysis and acidogenesis.

Removal efficiencies were high, $92-98 \%$ of COD $_{\text {total, }}$ TSS, and VSS, and $85-92 \%$ of $\mathrm{COD}_{\mathrm{diss}}$, for the entire reactors system (R1-3). In the R1 there were no removals of $\mathrm{COD}_{\text {total }}$ in the test 3 or of TSS and VSS in the tests 2, 3 and 4. The VW addition in tests $2-4$ and highest liquid velocity in reactor $\left(v=2.3 \mathrm{~m} \mathrm{~d}^{-1}\right)$ caused the loss of SS with the effluent from R1. Reactor 2 removed a large portion of $\mathrm{COD}_{\text {total }}(85-90 \%), \mathrm{COD}_{\text {diss }}(60-76 \%)$, TSS (94-98\%), and VSS (95-98\%), possibly reflecting the $4.5 \mathrm{~d}$ of HDT and $1.0 \mathrm{~m} \mathrm{~d}^{-1}$ of liquid velocity. Therefore, reactors system (R1-3) had a somewhat higher removal efficiency of COD and SS with an HDT of $13 \mathrm{~d}$ than R1-2 system with an HDT of $6.5 \mathrm{~d}$ and removal efficiencies of $\mathrm{COD}_{\text {total }} 90-95 \%, \mathrm{COD}_{\text {diss }} 78-87 \%$, TSS $87-97 \%$, and VSS $89-97 \%$. Despite the reduced removal efficiencies of R1 and $\mathrm{R} 3$, these reactors contributed the stability and high removals of organic matter and effluent quality in the treatment system (R1 + R2 + R3) (Table 4 and Fig. 2).

The reactors system R1-2 had a higher removal efficiency of $\mathrm{COD}_{\text {total }}(90-95 \%), \mathrm{COD}_{\text {diss }}$ (78-87\%), TSS (87-97\%), and VSS (89-97\%) with an HDT of $6.5 \mathrm{~d}$ if compared to the maximum $\mathrm{COD}_{\text {total }}$ removal of $84 \%$ with the HDT of $24 \mathrm{~d}$, and maximum removals of $\mathrm{COD}_{\text {diss }}(85 \%)$, TS (42\%) and VS (70\%) with HDT of 


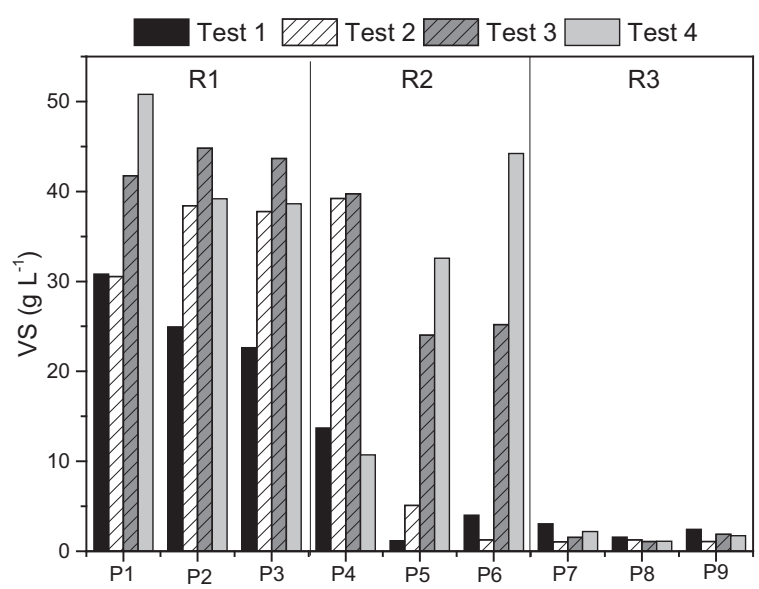

Fig. 4. Average values of volatile solids (VS) in the sludge collected in R1 (P1-3), R2 (P4-6) and R3 (P7-9) of three in-series high-rate horizontal anaerobic reactors with fixed bed (HARFB: R1, R2 and R3 - first, second and third), during the tests 1 (100\% SW), 2 (90\% SW:10\% VW), 3 (80\% SW:20\% VW), and 4 (70\% SW:30\% VW).

$16 \mathrm{~d}$, in a continuous methanogenic reactor (CSTR) with OLR of 3.6 and $5.4 \mathrm{~g} \mathrm{COD}_{\text {total }}(\mathrm{L} \mathrm{d})^{-1}$ used for co-digestion of pre-acidified ensiled sorghum, cheese whey and liquid cow manure. With HDT of $12 \mathrm{~d}$ and OLR of $7.2 \mathrm{~g} \mathrm{COD}_{\text {total }}(\mathrm{Ld})^{-1}, \mathrm{COD}_{\text {total }}, \mathrm{COD}_{\text {diss }}$, TS and VS removals declined by $39 \%, 23 \%, 26 \%$, and $46 \%$, respectively (Dareioti and Kornaros, 2015).

With mixture of $25 \%, 50 \%$, and $75 \%$ waste from vegetableprocessing factory and $75 \%, 50 \%$ and $25 \%$ swine waste, respectively, Molinuevo-Salces et al. (2013) obtained VS removals of $62.5 \%$, $81.4 \%$ and $85.5 \%$ in anaerobic batch bottles incubated for up to $80 \mathrm{~d}$. These values are lower than those obtained with the reactor system R1-2 with HDT of $6.5 \mathrm{~d}$. Arhoun et al. (2013) concluded that continuous feed allowed the treatment of almost double the waste ( 10.5 vs $6.0 \mathrm{~g}(\mathrm{~L} \mathrm{~d})^{-1}$ ) with the same biogas specific production and larger methane concentration than the discontinuous supplying protocol. The continuous feed limited the sudden production of important amounts of fatty acids that took place upon the discontinuous feed and were responsible for the $\mathrm{pH}$ decrease.

Thus, in-series high-rate HARFB system with continuous feed should provide an excellent alternative for the co-digestion of SW and VW, with good levels of organic matter removal and effluent quality, low HDT and high OLR.

\subsection{2. $\mathrm{CH}_{4}$ production}

Co-digestion of VW and SW was favorable for biogas production (Fig. 3 and Table 6). VW (banana and tomato) usually have higher concentrations of soluble carbohydrate than protein, as well as high water content, which favors substrate biodegradation and increases the methane production, as it was observed in the tests $2-4$. Di Maria et al. (2015) reported that fruit and vegetable wastes are favorable substrates for co-digestion processes, because in addition to maximizing the biogas production, they also stabilize the reactor. In tests 2-4 were observed lower variation coefficients (v.c.) than test 1 for removal efficiencies of $\operatorname{COD}_{\text {diss }}$ (Table 4 and Fig. 2) and methane volumetric and specific productions (Table 5 ) in reactors system. This showed higher stability with mixture of VW and SW.

$\mathrm{CH}_{4}$ percentage in biogas was higher in the test $1(100 \% \mathrm{SW})$ and decreased from 80 to $58 \%$ (R1), 83 to $33 \%$ (R2) and from 81 to $71 \%$ (R3) in the test 4 with $30 \% \mathrm{VW}$. In R1 occurred higher volumetric methane production in the tests 1-4, but with VW mixture the highest methane percentages in biogas occurred in R2 (tests 2-3) and R3 (test 4) (Table 6). The fast organic matter degradation from VW and higher OLR in reactor (R1) increased VFA and $\mathrm{CO}_{2}$ production from hydrolysis and acidogenesis reactions. Arhoun et al. (2013) observed similar results with significant reductions of methane percentage and biogas production when OLR was increased of $6.0-7.5 \mathrm{~g}$ VS $(\mathrm{Ld})^{-1}$ in reactor discontinuously fed and of $10.0-12.0 \mathrm{~g} \mathrm{VS}(\mathrm{L} \mathrm{d})^{-1}$ in reactor continuously fed with pear waste and anaerobic sludge. The biogas produced in the tests 2-4 and R1 contained more $\mathrm{CO}_{2}$. With acidic conditions occurred high VFA concentrations, the carbonic acid predominated and was released as gaseous $\mathrm{CO}_{2}$ with biogas, becoming unavailable for archaea produce methane.

Low methane volumetric production in the first $30 \mathrm{~d}$ (Fig. 3) was due to the start-up of the reactors, when the microbiota was still adapting.

The highest methane volumetric production in the reactors system $(R 1+R 2+R 3)$ occurred during the test 3 when the methane production was greater in R1 and R2 (Table 6). The biofilm and interstitial active sludge formed during the operation of the reactors was also increasing in those HARFB (Fig. 4) and favored the mass transport between of substrate in wastewater to microorganisms for methane conversion.

Volumetric methane production increased with OLR and VW addition in the tests $1-4$. The highest values were obtained in R1 in the tests $3-4$. The test 4 had almost the double of the OLR $\left(11.0 \mathrm{~g} \mathrm{COD}_{\text {total }}(\mathrm{Ld})^{-1}\right)$ than the test $3\left(5.2 \mathrm{~g} \mathrm{COD}_{\text {total }}(\mathrm{Ld})^{-1}\right)$, despite this, $\mathrm{R} 1$ methane volumetric production during the test 4 was not as high as it was expected. That occurred because it

Table 6

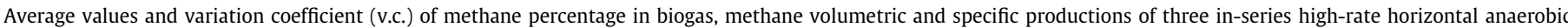
reactors with fixed bed (HARFB) during the tests 1-4.

\begin{tabular}{|c|c|c|c|c|c|c|c|c|c|}
\hline \multirow[t]{2}{*}{ Parameter } & \multirow[t]{2}{*}{ Measurement site } & \multicolumn{8}{|c|}{ Test (\%SW:\%VW) } \\
\hline & & $\begin{array}{l}1 \\
(100: 0)\end{array}$ & v.c & $\begin{array}{l}2 \\
(90: 10)\end{array}$ & v.c. & $\begin{array}{l}3 \\
(80: 20)\end{array}$ & v.c. & $\begin{array}{l}4 \\
(70: 30)\end{array}$ & v.c. \\
\hline \multirow{3}{*}{ Methane percentage in biogas (1) } & $\mathrm{R} 1$ & 80 & 7 & 73 & 13 & 70 & 8 & 58 & 5 \\
\hline & $\mathrm{R} 2$ & 83 & 5 & 77 & 12 & 75 & 6 & 33 & 51 \\
\hline & R3 & 81 & 11 & 82 & 8 & 73 & 8 & 71 & 5 \\
\hline \multirow[t]{4}{*}{ Methane volumetric production (2) } & $\mathrm{R} 1$ & 0.63 & 42 & 0.65 & 35 & 0.99 & 31 & 1.08 & 32 \\
\hline & $\mathrm{R} 2$ & 0.13 & 48 & 0.20 & 34 & 0.30 & 24 & 0.01 & 55 \\
\hline & R3 & 0.01 & 47 & 0.02 & 87 & 0.02 & 58 & 0.01 & 33 \\
\hline & $\mathrm{R} 1+\mathrm{R} 2+\mathrm{R} 3$ & 0.15 & 39 & 0.17 & 28 & 0.26 & 21 & 0.20 & 23 \\
\hline \multirow[t]{4}{*}{ Methane specific production (3) } & $\mathrm{R} 1$ & 0.15 & 40 & 0.22 & 35 & - & - & 0.25 & 12 \\
\hline & $\mathrm{R} 2$ & 0.21 & 56 & 0.16 & 49 & 0.12 & 38 & 0.02 & 55 \\
\hline & R3 & 0.22 & 38 & 0.21 & 33 & 0.22 & 37 & 0.21 & 31 \\
\hline & $\mathrm{R} 1+\mathrm{R} 2+\mathrm{R} 3$ & 0.19 & 58 & 0.30 & 39 & 0.14 & 24 & 0.10 & 56 \\
\hline
\end{tabular}

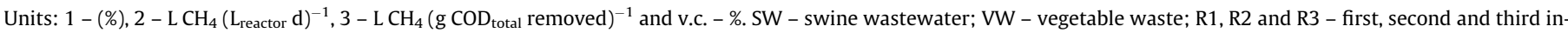
series HARFB. 
increased VSS ( $8610 \mathrm{mg} \mathrm{L}^{-1}$ ) in affluent during the test 4 and made the hydrolysis difficult. The test 4 coincided with the end of swine termination phase, when the VSS concentration increases in manure. Therefore, high amounts of organic matter were removed (97$98 \%$ ) but not all were converted to methane. These VSS accumulated as sludge in fixed bed interstices, mainly in R2 (Fig. 4).

Smaller volumetric methane productions in R2-3 occurred due to the higher amount of organic matter recalcitrant its affluent. This occurred as a result of removal of easily degradable organic matter in R1, especially in the tests $1-2$. Thus, lower conversion of organic matter occurred in R2-3 and little microbial biomass was generated, causing minor sludge accumulation. Also, sludge stratification occurs in horizontal reactors (plug flow) and inseries. Regions of the anaerobic reactor with greater VS concentrations in the sludge usually had the highest microbial activities and better sedimentation characteristics (Oliveira et al., 1997). Therefore, the reduced methane production could also be justified by the lower amount of sludge in the R2-3 (Fig. 4).

However, even with those variations, the methane percentage in biogas and methane volumetric production remained high (Table 5), evidencing the advantages of HARFB with continuous fed for organic matter conversion, when compared to other anaerobic co-digestion studies. Dareioti and Kornaros (2015) obtained methane volumetric production of $0.90 \mathrm{~L}(\mathrm{Ld})^{-1}$ with OLR of $5.4 \mathrm{~g} \mathrm{COD}(\mathrm{L} \mathrm{d})^{-1}$ and HDT of $16 \mathrm{~d}$ at $37^{\circ} \mathrm{C}$. Fonoll et al. (2015) observed in $2.5 \mathrm{~L}$ stirred-tank reactors semi-continuously fed with banana and sewage sludge $1.15 \mathrm{~L} \mathrm{CH}_{4}(\mathrm{~L} \mathrm{~d})^{-1}$ with OLR of $3.0 \mathrm{~g} \mathrm{VS}$ $(\mathrm{L} \mathrm{d})^{-1}$ and HDT of $20 \mathrm{~d}$ at $37^{\circ} \mathrm{C}$. Ganesh et al. (2013) applied higher OLR, of $7.5 \mathrm{~g} \mathrm{VS}(\mathrm{L} \mathrm{d})^{-1}$, and reported $0.94 \mathrm{~L} \mathrm{CH}_{4}(\mathrm{~L} \mathrm{~d})^{-1}$ with HDT of $37 \mathrm{~d}$ at $35^{\circ} \mathrm{C}$ operating a high organic load digester with fruit, vegetables, grass and bovine manure. With much lower HDT (2.0 d in R1), without temperature control (average 20$24{ }^{\circ} \mathrm{C}$ ), and OLR similar (5.2 and $11.0 \mathrm{~g} \mathrm{COD}_{\text {total }}(\mathrm{Ld})^{-1}$ in R1), in the tests 3 and 4, the methane volumetric productions were near, 0.99 and $1.08 \mathrm{~L}(\mathrm{~L} \mathrm{~d})^{-1}$ in R1 (Table 6). These results highlighted the better performance of HARFB, which can produce the same volume of methane with volume of reactors until eighteen times smaller.

The methane specific production in $\mathrm{R} 1$ increased from 0.15 to 0.22 and $0.25 \mathrm{~L}$ ( $\mathrm{g} \mathrm{COD}_{\text {total }}$ removed $)^{-1}$ from test 1 to tests 2 and 4 , indicating that increasing VW and OLR improved conversion of $\mathrm{COD}_{\text {total }}$ removed in methane of $43-71 \%$ in HARFB. The highest value in reactors system ( $\mathrm{R} 1+\mathrm{R} 2+\mathrm{R} 3)$ was in the test $2,0.30 \mathrm{~L}$ ( g COD $_{\text {total }}$ removed $)^{-1}$, so $86 \%$ of the removed COD was converted into methane (Table 6).

Similar methane specific production of $0.22 \mathrm{~L}$ (g COD removed $)^{-1}$, with OLR of 3.6 and $\left.5.4 \mathrm{~g} \mathrm{COD} \mathrm{(L} \mathrm{d}\right)^{-1}$, HDT of 24 and $16 \mathrm{~d}$, and at $37{ }^{\circ} \mathrm{C}$, was achieved by Dareioti and Kornaros (2015). Ganesh et al. (2013) observed values of 0.43 and $0.50 \mathrm{~L}$ (g VS removed $)^{-1}$ with OLR of 1.5-7.5 g VS (L d ${ }^{-1}$, HDT of 158$37 \mathrm{~d}$, and at $35^{\circ} \mathrm{C}$. Fonoll et al. (2015) reported 0.30 and $0.24 \mathrm{~L}$ (g VS removed) with OLR of 3.0 and $1.2 \mathrm{~g} \mathrm{VS} \mathrm{(L} \mathrm{d)})^{-1}$, HDT of $20 \mathrm{~d}$, and at $37^{\circ} \mathrm{C}$. These values were similar or lower than those of R1 in the tests 2 and 4 , confirming the better performance of the HARFB also for the $\mathrm{COD}_{\text {total }}$ removed conversion into methane. Therefore, even with much lower HDT ( $2.0 \mathrm{~d}$ ) in R1, the characteristics of reactors and affluent SW:VW, and the operating conditions were adequate in order to ensure efficient contact, absorption and conversion of organic matter by microorganisms in HARFB.

The HARFB were built with different diameters and volumes, so that there would be separation among the hydrolytic, acidogenic (R1) and methanogenic (R2 and R3) phases with higher liquid velocity and OLR in the first reactor and lower in second and third reactors. However, under the OLR and VW conditions tested, there was methanogenesis in all reactors, indicating the possibility for VW proportions and OLR to be increased.

\subsubsection{Removal of total and thermotolerant coliforms}

Aiming to improve the quality of the effluent to avoid a possible contamination by pathogenic microorganisms, the microbiological quality of affluents and effluents was analyzed (Table 7). High concentrations of total and thermotolerant coliforms of $2.4 \times 10^{8}$ to $1.2 \times 10^{10} \mathrm{MPN}(100 \mathrm{ml})^{-1}$ and of $2.1 \times 10^{8}$ to $6.6 \times 10^{9} \mathrm{MPN}$ $(100 \mathrm{ml})^{-1}$, respectively, were reported in SW by Pereira-Ramirez et al. (2004), Sylvestre et al. (2014) and Ramires and Oliveira (2014). Similar counts up to $2.1 \times 10^{10}$ and $1.7 \times 10^{9} \mathrm{MPN}$ $(100 \mathrm{ml})^{-1}$ of total and thermotolerant coliforms, respectively, occurred in the test $1(100 \% \mathrm{SW})$ (Table 7$)$, confirming the high level of microbiological contamination indicators in the affluent. The increase of $\mathrm{VW}$ in affluent reduced total and thermotolerant coliforms in test 4 to $1.7 \times 10^{6}$ and $1.4 \times 10^{6} \mathrm{MPN}(100 \mathrm{~mL})^{-1}$, respectively (Table 7). According to Salsali et al. (2006), the low $\mathrm{pH}$ and high concentrations of VFA may reduce the concentration of coliforms. With higher VW proportion and organic load in test 4 , VW biodegradation decreased affluent $\mathrm{pH}$ to 5.2 and increased VFA to $4441 \mathrm{mg} \mathrm{L}^{-1}$, causing growth inhibition and inactivation of coliforms.

The decreased counts of coliforms in-series HARFB (R1 + R2 $+\mathrm{R} 3$ ), especially after the addition of VW, was demonstrated by values of $1.7 \times 10^{7}$ and $1.8 \times 10^{4} \mathrm{MPN}(100 \mathrm{ml})^{-1}$ for total coliforms and $4.5 \times 10^{6}$ and $1.8 \times 10^{4} \mathrm{MPN}(100 \mathrm{ml})^{-1}$ for thermotolerant coliforms in the effluents from R3 in the tests 1 and 4 , respectively (Table 7 ).

The contribution of co-digestion with VW to remove total and thermotolerant coliforms was of $2 \log$ units in-series HARFB. Considering the decrease of coliforms concentrations with the VW mixture in SW would be 5-6 log units.

Table 7

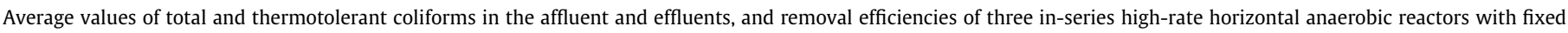
bed (HARFB) during the tests 1 and 4 .

\begin{tabular}{|c|c|c|c|c|c|}
\hline \multirow{3}{*}{$\begin{array}{l}\text { Test } \\
\text { (\%SW:\%VW) }\end{array}$} & \multirow[t]{3}{*}{ Measurement site } & \multicolumn{4}{|l|}{ Coliforms } \\
\hline & & \multicolumn{2}{|l|}{ Total } & \multicolumn{2}{|l|}{ Thermotolerant } \\
\hline & & MPN $(100 \mathrm{ml})^{-1}$ & Removal (\%) & MPN $(100 \mathrm{ml})^{-1}$ & Removal (\%) \\
\hline \multirow{5}{*}{$\begin{array}{ll} & \\
& \\
& (100: 0)\end{array}$} & Affluent & $2.1 \times 10^{10}$ & - & $1.7 \times 10^{9}$ & - \\
\hline & $\mathrm{R} 1$ & $2.1 \times 10^{8}$ & 99.00 & $1.1 \times 10^{7}$ & 99.35 \\
\hline & $\mathrm{R} 2$ & $1.7 \times 10^{8}$ & 19.04 & $7.8 \times 10^{6}$ & 29.09 \\
\hline & $\mathrm{R} 3$ & $1.7 \times 10^{7}$ & 90.00 & $4.5 \times 10^{6}$ & 42.30 \\
\hline & $\mathrm{R} 1+\mathrm{R} 2+\mathrm{R} 3$ & - & 99.92 & - & 99.73 \\
\hline \multirow{5}{*}{$4 \quad(70: 30)$} & Affluent & $1.7 \times 10^{6}$ & - & $1.4 \times 10^{6}$ & - \\
\hline & $\mathrm{R} 1$ & $1.7 \times 10^{6}$ & 0.00 & $1.4 \times 10^{6}$ & 0.00 \\
\hline & $\mathrm{R} 2$ & $1.1 \times 10^{6}$ & 35.29 & $1.1 \times 10^{6}$ & 21.43 \\
\hline & R3 & $1.8 \times 10^{4}$ & 98.36 & $1.8 \times 10^{4}$ & 98.36 \\
\hline & $\mathrm{R} 1+\mathrm{R} 2+\mathrm{R} 3$ & - & 98.94 & - & 98.71 \\
\hline
\end{tabular}

MPN = most probable number; SW - swine wastewater; VW - vegetable waste; R1, R2 and R3 - first, second and third in-series HARFB 
The removal efficiency of thermotolerant coliforms in-series HARFB was significant, 99.7\% in test 1 and $98.7 \%$ in test 4 (Table 7 ). Lower thermotolerant coliforms removals up to $96 \%$ occurred in SW treatment in UASB reactor and anaerobic filter with OLR of $23 \mathrm{~g} \mathrm{COD} \mathrm{(L} \mathrm{d})^{-1}$ and HDT of $20.5 \mathrm{~h}$ (Pereira-Ramirez et al., 2004). Similar removals of $99.8 \%$ and $99.9 \%$ of thermotolerant coliforms at OLR of 9.7 and $13.2 \mathrm{~g}$ COD total (L d $)^{-1}$, and HDT of 54 and $44 \mathrm{~h}$ were reported by Sylvestre et al. (2014) and Ramires and Oliveira (2014) in SW treated in systems with UASB reactors, anaerobic filter, biological filter and decanter. The anaerobic-aerobic treatment system used by Sylvestre et al. (2014), higher HDT (13 d) in-series HARFB and co-digestion with VW still were not enough to achieve removal of thermotolerant coliforms above 99.9\%. Valencia et al. (2009) performed co-digestion of municipal solid waste and septic tank sludge in bioreactor landfill simulators and after $450 \mathrm{~d}$ at $30^{\circ} \mathrm{C}$ achieved $100 \%$ removal of thermotolerant coliforms. Sylvestre et al. (2014) concluded that greater HDT results in more significant removal efficiency of thermotolerant coliforms. Thus, higher HDT at $\mathrm{R} 3$ or the inclusion of an additional reactor could improve the removal of thermotolerant coliforms in-series HARFB.

\section{Conclusions}

Increasing the VW and OLR in a co-digestion of VW and SW in high-rate HARFB provided excellent buffering capacity, avoided the inhibition of methane production by high VFA concentrations, and maintained appropriate nutrient concentrations; these factors enabled over $85 \%$ removal of total and dissolved COD, $90 \%$ of total and volatile suspended solids and $98 \%$ of total and thermotolerant coliforms. Maximal methane production of $1.08 \mathrm{~L} \mathrm{CH}_{4}(\mathrm{~L} \mathrm{~d})^{-1}$ with $70 \%$ of $\mathrm{COD}_{\text {total }}$ removed converted into methane was achieved by using $70 \%$ SW and 30\% VW.

\section{Acknowledgments}

We thank the Coordination for the Improvement of Higher Education Personnel (CAPES; Process PNPD-3137/2010) and the National Council for Scientific and Technological Development (CNPq; Process 483118/2011-7) for financial support and scholarship to the first author.

\section{References}

Abouelenien, F., Namba, Y., Kosseva, M.R., Nishio, N., Nakashimada, Y., 2014. Enhancement of methane production from co-digestion of chicken manure with agricultural wastes. Bioresour. Technol. 159, 80-87.

Angelidaki, I., Ahring, B.K., 1993. Applied microbiology biotechnology. Appl. Microbiol. Biotechnol., 560-564

APHA, 2005. Standard Methods for the Examination of Water and Wastewater, 21th ed. American Water Works Association/American Public Works Association/Water Environment Federation. American Public Health Association, Washington DC, USA.

Appels, L., Lauwers, J., Degrève, J., Helsen, L., Lievens, B., Willems, K., Van Impe, J., Dewil, R., 2011. Anaerobic digestion in global bio-energy production: potential and research challenges. Renew. Sustain. Energy Rev. 15, 4295-4301.

Arhoun, B., Bakkali, A., El Mail, R., Rodriguez-Maroto, J.M., Garcia-Herruzo, F., 2013. Biogas production from pear residues using sludge from a wastewater treatment plant digester. Influence of the feed delivery procedure. Bioresour. Technol. 127, 242-247.

Bolzonella, D., Battistoni, P., Susini, C., Cecchi, F., 2006. Anaerobic codigestion of waste activated sludge and OFMSW: the experiences of Viareggio and Treviso plants (Italy). Water Sci. Technol. 53, 203.

Bouallagui, H., Lahdheb, H., Romdan, E. Ben, Rachdi, B., Hamdi, M., 2009. Improvement of fruit and vegetable waste anaerobic digestion performance and stability with co-substrates addition. J. Environ. Manage. 90, 1844-1849.

Chen, Y., Luo, J., Yan, Y., Feng, L., 2013. Enhanced production of short-chain fatty acid by co-fermentation of waste activated sludge and kitchen waste under alkaline conditions and its application to microbial fuel cells. Appl. Energy 102, 11971204.

Dareioti, M.A., Kornaros, M., 2015. Anaerobic mesophilic co-digestion of ensiled sorghum, cheese whey and liquid cow manure in a two-stage CSTR system: effect of hydraulic retention time. Bioresour. Technol. 175, 553-562.
Di Maria, F., Sordi, A., Cirulli, G., Micale, C., 2015. Amount of energy recoverable from an existing sludge digester with the co-digestion with fruit and vegetable waste at reduced retention time. Appl. Energy 150, 9-14.

DiLallo, R., Albertson, O.E., 1961. Volatile acids by direct titration. J. Water Poll. Control Fed. 33 (4), 356.

Duda, R.M., da Silva Vantini, J., Martins, L.S., de Mello Varani, A., Lemos, M.V.F., Ferro M.I.T., de Oliveira, R.A., 2015. A balanced microbiota efficiently produces methane in a novel high-rate horizontal anaerobic reactor for the treatment of swine wastewater. Bioresour. Technol. 197, 152-160.

FAO, 2011. In: International Congress SAVE FOOD. Global Food Losses and Food Waste, Dusseldorf, p. 38.

Fernández, A., Sánchez, A., Font, X., 2005. Anaerobic co-digestion of a simulated organic fraction of municipal solid wastes and fats of animal and vegetable origin. Biochem. Eng. J. 26, 22-28.

Fonoll, X., Astals, S., Dosta, J., Mata-Alvarez, J., 2015. Anaerobic co-digestion of sewage sludge and fruit wastes: evaluation of the transitory states when the cosubstrate is changed. Chem. Eng. J. 262, 1268-1274.

Henz, G.P., Moretti, C.L.M., 2005. Tomate: Manejo pós-colheita. Cultiv. HF, 24-28.

Ganesh, R., Torrijos, M., Sousbie, P., Steyer, J.P., Lugardon, A., Delgenes, J.P., 2013. Anaerobic co-digestion of solid waste: effect of increasing organic loading rates and characterization of the solubilised organic matter. Bioresour. Technol. 130 $559-569$.

Ghaniyari-Benis, S., Borja, R., Monemian, S.A., Goodarzi, V., 2009. Anaerobic treatment of synthetic medium-strength wastewater using a multistage biofilm reactor. Bioresour. Technol. 100, 1740-1745.

Gissén, C., Prade, T., Kreuger, E., Nges, I.A., Rosenqvist, H., Svensson, S.E., Lantz, M. Mattsson, J.E., Börjesson, P., Björnsson, L., 2014. Comparing energy crops for biogas production - yields, energy input and costs in cultivation using digestate and mineral fertilisation. Biomass Bioenergy 64, 199-210.

Jenkins, S.R., Morgan, J.M., Sawyer, C.L., 1983. Measuring anaerobic sludge digestion and growth by a simple alkalimetric titration. J. Water Pollut. Control Fed. 55 (5), 448-453.

Jiang, Y., Heaven, S., Banks, C.J., 2012. Strategies for stable anaerobic digestion of vegetable waste. Renew. Energy 44, 206-214.

Kim, J., Park, C., Kim, T.-H., Lee, M., Kim, S., Kim, S.-W., Lee, J., 2003. Effects of various pretreatments for enhanced anaerobic digestion with waste activated sludge. J. Biosci. Bioeng. 95, 271-275.

Leite, V.D., de Sousa, J.T., Lopes, W.S., Henrique, I.N., Barros, A.J., 2014. Bioestabilização anaeróbia de resíduos sólidos orgânicos: aspectos quantitativos. Tecno-Lógica 18, 90-96.

Lichtemberg, L.A., Boas, E.V.B.V., Dias, M.S.C., 2008. Bananicultura irrigada: inovações tecnológicas. Inf. Agropecuário 29, 92-110.

Lin, J., Zuo, J., Gan, L., Li, P., Liu, F., Wang, K., Chen, L., Gan, H., 2011. Effects of mixture ratio on anaerobic co-digestion with fruit and vegetable waste and food waste of China. J. Environ. Sci. 23, 1403-1408.

Liu, X., Gao, X., Wang, W., Zheng, L., Zhou, Y., Sun, Y., 2012. Pilot-scale anaerobic codigestion of municipal biomass waste: focusing on biogas production and GHG reduction. Renew. Energy 44, 463-468.

McGlone, J.J., 2013. The future of pork production in the world: towards sustainable, welfare-positive systems. Animals 3, 401-415.

Molinuevo-Salces, B., Gómez, X., Morán, A., García-González, M.C., 2013. Anaerobic co-digestion of livestock and vegetable processing wastes: fibre degradation and digestate stability. Waste Manage. 33, 1332-1338.

Murto, M., Björnsson, L., Mattiasson, B., 2004. Impact of food industrial waste on anaerobic co-digestion of sewage sludge and pig manure. J. Environ. Manage. 70, 101-107.

Nagao, N., Tajima, N., Kawai, M., Niwa, C., Kurosawa, N., Matsuyama, T., Yusoff, F.M., Toda, T., 2012. Maximum organic loading rate for the single-stage wet anaerobic digestion of food waste. Bioresour. Technol. 118, 210-218.

Namsree, P., Suvajittanont, W., Puttanlek, C., Uttapap, D., Rungsardthong, V., 2012. Anaerobic digestion of pineapple pulp and peel in a plug-flow reactor. J. Environ. Manage. 110, 40-47.

Nielsen, H.B., Angelidaki, I., 2008. Strategies for optimizing recovery of the biogas process following ammonia inhibition. Bioresour. Technol. 99, 7995-8001.

de Oliveira, R.A., Bruno, N.M.N., 2013. Start-up of horizontal anaerobic reactors with sludge blanket and fixed bed for wastewater treatment from coffee processing by wet method. Eng. Agric. 33, 353-366.

de Oliveira, R.A., Vazoller, R.F., Foresti, E., 1997. Sludge bed characteristics of UASB reactors: growth, activity, microbial structure and chemical composition of granules. In: 8th International Conference on Anaerobic Digestion. International Association Water Quality, Sendai, pp. 524-531.

Pereira-Ramirez, O., Quadro, M.S., Antunes, R.M., Koetz, P.R., 2004. Influência da recirculação e da alcalinidade no desempenho de um reator UASB no tratamento de efluente de suinocultura. Rev. Bras. Agrociência 10, 103-110.

Ramires, R. delA., de Oliveira, R.A., 2014. COD, TSS, nutrients and coliforms removals in UASB reactors in two stages treating swine wastewater. Eng. Agric. 34, 12561269.

Ripley, L.E., Boyle, W.C., Converse, J.C., 1986. Improved alkalimetric monitoring for anaerobic digestion of high-strength wastes. J. Water Pollut. Control. Fed. 58 406-411.

Salsali, H.R., Parker, W.J., Sattar, S.A., 2006. Impact of concentration, temperature, and $\mathrm{pH}$ on inactivation of Salmonella spp. by volatile fatty acids in anaerobic digestion. Can. J. Microbiol. 52 (4), 279-286.

dos Santos, A.C., de Oliveira, R.A., 2011. Tratamento de águas residuárias de suinocultura em reatores anaeróbios horizontais seguidos de reator aeróbio em batelada sequencial. Eng. Agric. 31, 781-794. 
Sauer, J., Dahmen, N., Henrich, E., 2015. Chemical Reactor Types. Encycl. Ind. Chem. Wiley-VCH Verlog GmbH \& Co. KGaA, pp. 1-2.

Sylvestre, S.H.Z., Lux Hoppe, E.G., de Oliveira, R.A., 2014. Removal of total coliforms, thermotolerant coliforms, and Helminth eggs in swine production wastewater treated in anaerobic and aerobic reactors. Int. J. Microbiol. 2014, 1-11.

Urbinati, E., Duda, R.M., de Oliveira, R.A., 2013. Performance of UASB reactors in two stages under different HRT. Eng. Agric. 23, 367-378.

Valencia, R., den Hamer, D., Komboi, J., Lubberding, H.J., Gijzen, H.J., 2009. Alternative treatment for septic tank sludge: co-digestion with municipal solid waste in bioreactor landfill simulators. J. Environ. Manage. 90, 940-945.

Wang, K., Yin, J., Shen, D., Li, N., 2014. Anaerobic digestion of food waste for volatile fatty acids (VFAs) production with different types of inoculum: effect of $\mathrm{pH}$ Bioresour. Technol. 161, 395-401.
Xie, S., Lawlor, P.G., Frost, J.P., Hu, Z., Zhan, X., 2011. Effect of pig manure to grass silage ratio on methane production in batch anaerobic co-digestion of concentrated pig manure and grass silage. Bioresour. Technol. 102, 5728-5733. Yang, D., Deng, L., Zheng, D., Liu, G., Yang, H., Wang, L., 2015. Separation of swine wastewater into solid fraction, concentrated slurry and dilute liquid and its influence on biogas production. Fuel 144, 237-243.

Zaiat, M., Cabral, A.K.A., Foresti, E., 1994. Reator anaeróbio horizontal de leito fixo para tratamento de águas residuárias: concepção e avaliação preliminar de desempenho. Rev. Bras. Eng. - Cad. Eng. Quím. 11, 33-42.

Zuo, Z., Wu, S., Zhang, W., Dong, R., 2013. Effects of organic loading rate and effluent recirculation on the performance of two-stage anaerobic digestion of vegetable waste. Bioresour. Technol. 146, 556-561. 